\title{
An Overview on Avian Influenza
}

\section{-Author(s)}

Nelson Rodrigo da Silva Martins

Professor Associado, Departamento de Medicina Veterinária Preventiva

Escola de Veterinária,UFMG

\section{ABSTRACT}

Avian influenza (Al) is considered an exotic disease in the Brazilian poultry industry, according to the National Avian Health Program (PNSA), with permanent monitoring of domestic, exotic and native avian species. Brazil presents privileged environmental conditions of reduced risk. In addition, all commercial poultry and conservation holdings are registered in state or national inventories and geographically located (GPS) for health control. Poultry health standards are adopted for the conformity to the international market, mostly for the intensified poultry destined for exportation, but also for companion exotic and native conservation facilities. Guidelines for monitoring and the diagnosis of Al are published by the PNSA and follow the standards proposed by the international health code (World Organization for Animal Health, Organization International des Epizooties - OIE) and insure the free of status for avian influenza virus (AIV) of LPAIV-low pathogenicity AIV and HPAIV-high pathogenicity AIV. In addition, the infections by mesogenic and velogenic Newcastle disease virus, Mycoplasma gallisepticum, $M$. synoviae and M. meleagridis, Salmonella enteric subspecies enterica serovar Gallinarum biovars Gallinarum and Pullorum are eradicated from reproduction. Controlled infections by S.enterica subspecies enterica serovars Enteritidis and Typhimurium are monitored for breeders. The vaccination of chickens in ovo or at hatch against Marek's disease is mandatory. Broiler production is an indoor activity, confinement which insures biosecurity, with safe distances from the potential AIV reservoir avian species. Worldwide HPAIV H5N1 notifications to the OIE, in March 2011, included 51 countries.

\section{INTRODUCTION}

Avian influenza (Al) is caused by influenza A virus of avian origin, which may cause disease in domestic and wild avian and mammalian species, including humans. The outbreaks caused by the high pathogenicity avian influenza virus (HPAIV) strains of subtype H5N1 of Asian origin have caused animal and human disease and mortality in several countries of Southeast Asia, such as Bangladesh, Cambodia, China, India, Indonesia, Laos, Myanmar, Thailand and Viet Nam. In some countries, HPAIV H5N1 has become endemic in domestic poultry, and caused the death or slaughter of 250 million birds, including potential reservoir species (OIE, 2010).

Since June 15, 2005, International Health Regulations were established to prevent, protect, control and respond to international risks to human health, enabling early alert and rapid network action. The Global Outbreak Alert and Response Network maintains epidemiological and operational data on disease events to allow correct and fast international communication, pillars of global health security (WHO, 2010). 
Human HPAIV risk factors for 15 hospitalized patients were associated to the $1997 \mathrm{H} 5 \mathrm{~N} 1$, after the death of a child in Hong Kong. Age, sex, neighborhood were evaluated, and the exposure to live chickens in markets was considered significant, while the consumption or preparation of food and human contact were not associated to disease, including respiratory diseases and influenza (Mounts et al., 1999). Chickens were considered the main source of H5N1 HPAIV in humans
It was speculated that a mild pandemic lasting 12 months would result in a local gross internal product loss of $3 \%$ and $0.5 \%$ worldwide, estimated between US\$ 150 and 200 billion. Contingency-prepared countries would respond rapidly and implement actions minimizing the economic and social impacts (WHO, 2009a). Estimates of losses were published for selected countries (Table 1).

Table 1 - Economic impact of influenza H5N1 outbreaks in selected Asian and African countries.

\begin{tabular}{|c|c|c|}
\hline Country & Cost & Author \\
\hline Bangladesh & Farm disinfection from US\$22.00 to US\$110.00 & Alam et al., 2008 \\
\hline Egypt & US\$30 million in compensation & Ibrahim et al., 2007 \\
\hline Hong Kong & $\begin{array}{l}\text { Loss of } 3.8 \text { million birds and US\$29.2 million in compensation during the outbreaks of } \\
1997,2001 \text { and } 2005 \text {. }\end{array}$ & APHCA, 2005 \\
\hline Malaysia & US\$50,000 per month for transit control (2005). & APHCA, 2005 \\
\hline Thailand & $\begin{array}{l}\text { First wave US\$ } 12.5 \text { million; second wave US\$ } 26 \text { million; repopulation of } 61 \text { million birds } \\
\text { US\$ } 29.2 \text { millions }\end{array}$ & DLD, 2004 \\
\hline Viet Nam & $\begin{array}{l}\text { US\$ } \$ .25 / \text { bird ( } 200 \text { bird flocks); US } \$ 1.00 \text { (1,000 bird flocks); } \\
\text { US\$ } 18.5 \text { million for repopulation of } 41 \text { million birds. }\end{array}$ & $\begin{array}{l}\text { Hinricks et al., } 2006 \\
\text { Riviere-Cinnamond, } 2005\end{array}$ \\
\hline
\end{tabular}

in Hong Kong, with reports of playing, slaughter, manipulation, defeathering of chickens and geese and preparation of meat from sick birds for consumption, with clusters of limited inter-human transmission were also reported (Ungchusak et al., 2005). Although H5N1 strains are widely disseminated in Asia, human cases are comparatively rare, and occur mainly in young healthy individuals. After 2005, however, the number of cases has increased, with the dissemination of H5N1 clade 2.2 strains to Eurasia and Africa, with rare cases of subclinical or mild infections. Human cases occur in eighteen year-old patients in average, and $90 \%$ of the patients are less than 40 years of age, with an average mortality rate of $61 \%$, which is higher in young people between 10-19 years of age and lower in people older than 50 . After the exposure to HPAIV H5N1 strains, the incubation period for the appearance of clinical signs may be around 7 days or less, and in most patients is 2-5 days, although in one cluster it took 8-9 days (Writing Committee, 2008).

\section{Economic impact}

Most countries affected with HPAIV H5N1 presented poultry losses of around $1 \%$ of GDP, reaching 0.6 in Viet Nam and Thailand and up, gradually expanding its avian host range. In June 2007, it affected 62 countries, with more than 250 million birds dead or slaughtered and an estimated impact of more than US\$ 12 billion.
An information system established by research, educational, and industrial institutions was previously recommended to reduce the impacts of the disease (Wei-Hua, 1998). Between 1983 and 2005, 356.64 million chickens were lost during the fight against different AIV subtype epizooties (Steensels et al., 2005). Since the Hong Kong H5N1 strain outbreaks of avian influenza in 1997, warnings of global pandemic were issued. H5N1 and derived strains have cost more than US\$10 billion in research, human life and losses to the poultry industry, with more than 200 million birds killed. In China, costs to farmers reached about US\$1 billion in 2004 and company sales declined up to US\$2.5 billion. The direct costs to Cambodia, Thailand and Vietnam reached US\$560 million in 2005 (Special Report, 2007).

Countries involved in global trade adopt the international animal health code and implement national regulations. A chronology of events from the primary outbreak to the return to production may be planned in order to organize the efforts for disease control. Losses in an affected region may result in benefits for an unaffected region. Regionalization and permanent partnership among public and private institutions may produce more adequate epidemiological studies, outbreak simulations, setting up the required services infrastructure, statistic and economic analyses, and an information system and network (Beach et al., 2007; Lichtenberg, 2002). 
The risk of detecting HPAIV infection was evaluated in Thailand, according to species and type, in 2004, when incidence was the highest. Quails (1.3\%) were found to be at the highest risk, followed by layers $(0.25 \%)$ and broilers $(0.25 \%)$, ducks and geese $(0.075 \%)$ and free-range chickens $(0.05 \%)$, with the lowest risk for the smaller backyard flocks (Otte et al., 2008a).

Thailand suffered the greatest impact of the disease in Jan-April 2004, with 75\% reduction in exports, followed by China, with $63 \%$ reduction, Hong Kong $(55 \%)$ and $27 \%$ in the USA, whereas Brazil was the only country that increased (6\%) exports (Taha, 2007).

Brazil was benefited by restrictions imposed on Asian poultry-exporting countries, particularly Thailand and Turkey, between 2003 and 2005. It doubled its non-processed meat sales, from US $\$ 1.5$ to 2.9 billion, and processed meat increased from US $\$ 220$ to 398 million for (Nicita, 2007). In 2006, most countries faced a retraction in consumer market of meat and eggs of around $30 \%$ in countries affected with the disease and $15 \%$ in unaffected countries, such as Argentina and Brazil (OIE, 2007). In 2006, poultry meat exports from China were reduced in 13\%, in 7\% from Brazil and in 2\% from the European Union (EU-25). That year, global market export shares reached $39 \%$ for the United States, 37\% for Brazil, EU-25 12\% and China $1.9 \%$. However, cooked meat exports share was $17 \%$ for Brazil, which increased from the 13\% obtained in 2005 (Taha, 2007).

\section{Influenza H1N1}

Several episodes of transmission between humans and swine have been reported, including the first report of interspecific transmission based on serology in 1938, and that from an U.S. Army soldier, who transmitted the virus to pigs and 500 people in 1976 (Kendal et al., 1977). In December, 2005, in Wisconsin, USA, a 17-year-old man, vaccinated against endemic influenza, was diagnosed infected with a triplereassortant $\mathrm{H} 1 \mathrm{~N} 1$ strain, presenting headache, nasal discharge, back pain and cough, but no fever. He had helped to eviscerate slaughtered healthy swine three days previously to clinical signs (Newman et al., 2008).

The 2009 H1N1 human pandemics reached more than 200 countries, with cases confirmed by laboratory diagnosis, and more than 15,000 deaths were recorded (CDC, 2010c) (Table 2a), with worldwide effects. It became the predominant strain of influenza (Assessment..., 2009). The infection was mostly restricted to the upper respiratory system and did not cause complications, although $40 \%$ of infected people suffered gastric and intestinal infection, with nausea and vomits (Myers et al., 2007; Dawood et al., 2009, Riquelme et al., 2009, Shinde et al., 2009). The 2009 H1N1 human pandemics was the largest in history by a reassortant swine virus (Garten et al., 2009, Shinde et al., 2009). The lower virulence of the $2009 \mathrm{H} 1 \mathrm{~N} 1$ virus strain may be partially attributed to the absence of the expression of the PB1-F2 protein, a major determinant of virus virulence known to cause cell death and found in viruses responsible for the major influenza pandemics of 1918-19 (H1N1), 1957 (H2N2), and 1968 (H3N2) (Report..., 2009). The $2009 \mathrm{H} 1 \mathrm{~N} 1$ case fatality rate was $0.6 \%(0.1 \%-5.1 \%)$ and deaths amounted to 18,156 (Table 2b), which, compared with the estimates, were much lower, indicating fatality overestimations and possibly effective mass vaccination and better health strategies and care (Wilson, 2010).

Table 2 - Characteristics of the three human influenza pandemics of the $20^{\text {th }}$ century.

\begin{tabular}{|c|c|c|c|c|c|c|c|}
\hline Pandemics & $\begin{array}{c}\text { Area of } \\
\text { emergence }\end{array}$ & Subtype & $\begin{array}{l}\text { Estimated } \\
\text { reproductive } \\
\text { No. }\end{array}$ & Estimated CFR ${ }^{1}$ & $\begin{array}{c}\text { Estimated } \\
\text { mortality } \\
\text { (actual) }\end{array}$ & $\begin{array}{l}\text { Most affected } \\
\text { age group }\end{array}$ & GDP2 loss \% \\
\hline $\begin{array}{l}\text { 1918-1919 } \\
\text { Spanish Flu }\end{array}$ & Unclear & H1N1 & $1.5-1.8$ & $2-3 \%$ & 20-50 million & Young adult & -16.9 to 2.4 \\
\hline $\begin{array}{l}\text { 1957-1958 } \\
\text { Asian Flu }\end{array}$ & South China & $\mathrm{H} 2 \mathrm{~N} 2$ & 1.5 & $<0.2 \%$ & 1-4 million & Children & -3.5 to 0.4 \\
\hline $\begin{array}{l}\text { 1968-1969 } \\
\text { Hong Kong Flu }\end{array}$ & South China & H3N2 & $1.3-1.6$ & $<0.2 \%$ & 1-4 million & All ages & -0.4 to 0.15 \\
\hline $\begin{array}{l}2009 \text { Influenza } \\
\text { A H1N13 }\end{array}$ & North America & H1N1 & $1.1-1.5$ & $0.1 \%-5.1 \%^{4}$ & $\begin{array}{c}150,000 \\
(15,000)^{5} \\
(18,156)^{6}\end{array}$ & $\begin{array}{l}\text { Teenagers and } \\
\text { young adults }\end{array}$ & Difficult ${ }^{3}$ \\
\hline
\end{tabular}

${ }^{1}$ Case fatality Rate; ${ }^{2}$ Gross Domestic Product; ${ }^{3}$ Assessment..., 2009; Pandemic..., 2009; ${ }^{4}$ Vaillant et al., 2009; Fraser et al., 2009; ${ }^{5}$ Assessment..., 2009; ${ }^{6}$ Wilson, 2010. 
Table $\mathbf{2 b}$ - Examples of some quoted death estimates from the next influenza pandemics, seasonal influenza death estimates and reported deaths from H1N1.

\begin{tabular}{lcc}
\hline $\begin{array}{l}\text { Pre-H1N1 predictions } \\
\text { of future pandemic } \\
\text { mortality }\end{array}$ & $\begin{array}{c}\text { Reported } \\
\text { H1N1deaths }\end{array}$ & $\begin{array}{c}\text { Estimates for seasonal } \\
\text { influenza }\end{array}$ \\
\hline $\begin{array}{l}\text { Canada } \\
17,768-41,459\end{array}$ & 428 & $2,000-8,000 /$ year \\
$\begin{array}{l}\text { Global } \\
\text { 2-7 million, best case- } \\
\text { scenario }\end{array}$ & 18,156 & $250,000-500,000 /$ year \\
62 million, based on 1918 & & \\
pandemic & & \\
\hline $\begin{array}{l}180-360 \text { million, based on } \\
\text { 1918 pandemic }\end{array}$ & \\
\hline Wilson (2010). & \\
\hline
\end{tabular}

Previous North American clusters were small (Lessler et al., 1976). However, the "American strain" of H1N1 (Qi et al., 2008) was characterized as the combination of four different origins, namely, avian North-American, human Mexican, human endemic and swine Asian/ European (Gabriel et al., 2008). Triple reassortant H1N1 strains, combining genes of AIV from birds, humans and swine, have previously emerged in the USA, specifically in 1998 (OIE, 2007). Epidemiological studies suggest that subtype $\mathrm{H} 1 \mathrm{~N} 1$ isolates with triple reassortment are the prevailing strains in North American swine (Olsen et al., 2006), and humans in direct contact with pigs are at risk (Wentworth et al., 1997; Olsen et al., 2002), although contact history was not always reported (Myers et al., 2007). In addition, a study on the nosocomial infection by H1N1 of 1,520 patients hospitalized in the United Kingdom with pandemic (H1N1) 2009 influenza, found that, out of 30 patients, 12/15 (80\%) adults and $14 / 15$ (93\%) children had important underlying illnesses (Enstone et al., 2011).

In Brazil, the 2010 (up to August 2010) American H1N1/2009 strain mass vaccination campaign reached about 89.5 million people (Brasil, Ministério da Saúde, 2011). During the 2009 H1N1 vaccination campaign, priority groups were vaccinated using a triple subtype vaccine, reaching more than 21 million people in 2010 and approximately seven million in 2011. The trivalent vaccine contained the H1N1 2009 strain and the campaign achieved about 80\% coverage (Secretaria do Estado da Saúde, 2011).

\section{Aiv evolution}

The "transition to error catastrophe", in which there is a breach of the threshold error, results in an irreversible transition to extinction (Domingo et al.,
2000). High mutation rates due to transcriptional errors are known to occur in RNA viruses (Palese \& Shaw, 2007). RNA virus species are considered a complex distribution of mutants, in accordance to the concept of quasi-species and in contrast to homogeneous genomes (Eigen et al., 1988, Domingo, 2007). RNA virus polymerases, including the retroviruses, do not display transcription error verification system (Wright et al., 2007). In contrast, larger genome viruses, consisting mainly of DNA, present an evolutionary transcriptional error verification system. The calculated mutational rate for RNA viruses may vary from $10^{-3}$ to $10^{-5}$ substitutions per copied nucleotide, representing, for a 3 to $32 \mathrm{~kb}$ RNA virus, an expected average mutation of 0.1 to 1 (Domingo, 2007). Considering these values, the AIV genome consisting of 13,600 nucleotides, may present, approximately, a minimum of 0.1 and maximum of 10 mutations per virion.

Recombination is a phenomenon of geneticexchange of portions of (markers) or whole segments between different segments of the genome. The recombination of entire segments, called re-assortment, occurs when a cell is co-infected by two different virus strains, resulting in hybrid-progeny viruses. Rearrangement is a common type of recombination in viruses with segmented genomes, such as influenza and other viruses. In RNA viruses with segmented genomes, recombination between markers in the same segment is extremely rare, but the rearrangement of segments is extremely effective as an evolutionary strategy of strains. The non-segmented RNA viruses of the Picornaviridae, Coronaviridae, Retroviridae, and Togaviridae families present recombination during replication by exchanging copies of different parental origins (Condit, 2007). For the influenza virus, the rearrangement of segments in cells co-infected by two different strains could result in 256 possible recombinants, with two parents and 254 products. This mechanism has generated several strains involved in pandemics, such as in 1957, 1968 and 2008 in humans, and the H5N1 avian pandemic influenza started in 1997. In humans, recombinant H1N2 strains were isolated in Europe in 1987-1988 concomitantly with circulating H1N1 and H3N2 strains (Condit, 2007).

Human cases of H5N1 infection are rare, and usually occur where the virus is endemic in poultry, when humans are exposed to infected birds or contaminated environments (Subbarao et al., 1998). Hence, sporadic human infection will occur if AIV circulates in poultry. By 12 March 2012, 596 human cases of infection with avian influenza A H5N1 had been confirmed in 15 
countries, as reported to WHO since 2003, out of which 350 died, with a fatality rate of $58.7 \%$ (WHO, 2012), with very limited human to human transmission, and stable or reduced human cases were reported since 2010 (FAO-OIE-WHO Technical Update, 2011).

\section{Global dissemination}

HPAIV H5N1 cumulative cases from 2003 to March 2012, as reported to OIE, were 2,655 in Viet Nam, 1,141 in Thailand, 1,084 in Egypt, 525 in Bangladesh, 273 in Romania,261 in Indonesia, 219 in Turkey, 149 in Russia, 114 in Myanmar, 112 in Korea, and 99 in China, including a total of 51 countries (OIE, 2012). Circulating H5N1 clades (1, 2.1.3, 2.2, 2.2.1, 2.3.2, 2.3.4 and 7) were examined for average within-group pairwise nucleotide distances, and found divergence greater than $1.5 \%$ within-group, indicating the need to split these groups into new order clades. Monophyletic groups of clade-specific trees resulted in the establishment of 12 new second-, third-, and fourth-order clades. However, thirteen clades $(0,2.1 .1$, 2.1.2, 2.3.1, 2.3.3, 2.4, 2.6, 3, 4, 5, 6, 8, and 9) have not been detected since at least 2008.(Updated..., 2011). Avian outbreaks have been documented since the late 1950s, including A/chicken/Scotland/59, A tern/South Africa/61 and A/turkey/England/63 and the various H5N1 viruses, widespread since 2003 (Swayne \& Halvorson, 2008)

Global data on poultry imports, exotic bird trade and bird migrations were combined in an integrative analysis with phylogenetic data, identifying the possible pathway of 36 out of the 52 viral introductions. Spread through Asia and to Africa involved both migratory birds and poultry trade, and to Europe, mostly migratory birds (20 out of 23 countries). The North American risk was considered an association of the introduction of infected poultry, indicating the existence of illegal trade, with the North-South American bird travel dissemination (Kilpatrick et al., 2006).

In 2005, a new event occurred in the region of the Qinghai Lake nature reserve in the community of Gangcha, Qinghai Province, China, with mortality of natural reservoir species, especially the barredhead goose, the brown and black head gull, ruddyshell ducks and great cormorant (Brydon et al., 2005, Kilbourne et al., 2004). The isolate sequences of the HA, NA and NP genes were similar to those of the A/chicken/Shantou/4231/2003 (H5N1) gene, whereas other genes were similar to the A/chicken/ Shantou/810/2005 (H5N1) strain found in Hong Kong in a peregrine falcon in 2004 and present in domestic chickens in 2005 (Kilbourne et al., 2004). In the middle of-2005, H5N1 strains derived from the isolates from Qinghai Lake Reservation, were found in Kazakhstan, Mongolia and Russia, and in 2006, these strains were spread across Southwestern and Central Europe, Africa and the Middle East (Palese \& Shaw, 2007).

An early warning system for HPAIV was established for surveillance in Alaska by the United States Geological Society. Sampling priority involves geographical areas used as corridors by migratory birds. The two main migratory routes monitored are East Asia-Australasia and East Asia-Southeast Asia-Arctic Siberia-Eastern Russia and Alaska. In the East Asia-Australasia route (20 countries), beach/shore birds of Russia, Siberian Arctic, Alaska and Southeast Asia, including North American islands of the Pacific, Australia and New Zealand are monitored for morbidity and mortality. Live wild birds, birds killed by hunters, poultry sentinels or sentinel ducks placed in aquatic and terrestrial habitats are also under surveillance (USGS, 2006). The frequency of exchange between AIV clades or superfamilies of Eurasia and America isolates of subtypes $\mathrm{H} 1$ to $\mathrm{H} 13$ and $\mathrm{N} 1$ to $\mathrm{N} 9$ were detected, but not of $\mathrm{H} 14$ and $\mathrm{H} 15$, in mallards of Alberta (Canada) and other birds, and seagulls in New Jersey (USA) between 2001 and 2006. HPAIV H5N1 strains were not detected in Eurasia and serological studies provided no confirmation of their movement into America. In North America, subtype $\mathrm{H} 16$ and an unusual cluster of H7N3, lethal to embryos, were found in beach birds and seagulls, but not in wild ducks. The results of 6,767 genetic analyses and 248 complete sequences suggested the lack of HPAIV H5N1 strains perpetuation in migratory birds and that its introduction from birds of Eurasia into America seems to be a rare event (Krauss et al., 2007).

However, the relationship between epidemiological dynamics and genetic diversity patterns is not known at a continental scale (Chen \& Holmes, 2009). The interface between migration routes in the northern hemisphere has allowed the exchange of infections, such as the transmission of AIV H2 into sea birds, from Asia to North America. Eurasian HA lineages were detected in North American AIV isolates, and considering that the 1957 pandemic was of the $\mathrm{H} 2$ sub-type, these data reinforce the need for continued surveillance (Marakova et al., 1999).

The inter-species transmission of AIV, regarding the H5N1 outbreaks in Hong Kong, was partially aborted in the region due to the application of euthanasia as the eradication strategy for markets of live birds and 
other poultry, and called attention to poultry as a source of virus for humans (Shortridge et al., 1998). Considering the high susceptibility of felines to this virus, a guide for the prevention and management of HPAIV H5N1 infection in cats was published (Thiry et al., 2009). Immediate recombination between HPAIV H5N1 of avian origin and H3N2 of human origin was demonstrated in ferrets (Mustela putorius), with co-infection. Five recombinant isolates showed evidence of lower nasal replication than the parental H5N1 strain, and were not transmitted by direct contact between recombinant ferrets. However, the authors considered the risk of shared infections due to human and ferret cohabitation (Jackson et al., 2009).

Studies suggest that birds of prey are susceptible to fatal infection by HPAIV strains. Antigenic studies, molecular phylogenetics and pathogenicity of H5N1 strains isolated from HPAIV hawks killed in Saudi Arabia (2005) and Kuwait (2007) were conducted. All isolates were grouped as of the Qinghai clade 2.2, but have spread to the West in different ways. The reasons for their rapid spread from Qinghai since the 2005 outbreaks are not completely understood, but the strains seem to have been transmitted to the hawks by migratory birds or by the illegal imports of quail to feed the hawks (Marjuki et al., 2009).

Biosecurity is the first line of defense for commercial poultry from diseases transmitted by other domestic and wild animals, fomites, tools, and contaminated shoes and clothing. Koch \& Elbers (2006) proposed biosecurity strategies for small, family-owned poultry farms. A South Korean outbreak of HPAIV H5N1, despite the intensive surveillance efforts, resulted in serious losses for local poultry production. Six strains were characterized; all belonged to the same subtype, and were grouped into clade 2.3 (from China and South East Asia), according to HA. However, internal structures and neuraminidase codes of recent human outbreaks have shown strains to be related to clade 2.3.4 of avian origin in southern Asia (Kim et al., 2009). A report of an HPAIV of Asian origin in Europe was published by the French Food Health Safety Agency (Rapport..., 2008), presenting the number of notifications during 2006, with the highest number from Germany (331), followed by Austria (117), France (65), Poland (64), Denmark (43), Greece (32), Slovenia (28), Sweden (21), Italy, Hungary (16), Czech Republic (14), Slovakia (2), Spain (1) and United Kingdom (1).

Free-living birds may transmit AIV when their environment is shared by several mechanical and biological means (Swayne \& Halvorson, 2008). The minimal molecular conditions for efficient AIV H9N2 transmission were studied and it was demonstrated that inter-specific transmission is required for the generation of HA gene point mutations and reassortment. Human H3N2 and avian H9N2 reassortants were studied in ferrets (Mustela putorius) as experimental mammalian model. H3N2 reassortants with H9N2 surface proteins were efficiently transmitted and generated a disease similar to that caused by parental H3N2. Minimal changes in subtype H9N2 strains may be needed for human transmission, enabling the possible emergence of further subtypes beyond the classical $\mathrm{H} 1, \mathrm{H} 2$ and $\mathrm{H} 3$ subtypes (Sorrell et al., 2009).

In the aquatic environment, AIV fecal-oral (indirect) transmission occurs when water is contaminated. The infection capacity of AIV strains of twelve different origins was studied in water with natural variation of $\mathrm{pH}$, salinity and temperature. Strains varied according to origin, but were in general stable in moderately alkaline water ( $\mathrm{pH} 7.4-8.2)$, at lower temperatures $(<17$ $\left.{ }^{\circ} \mathrm{C}\right)$ with low salinity or fresh water ( $\mathrm{Na}$ 0-20,000 ppm). In contrast, lower $\mathrm{pH}(<6.6)$, higher temperature $(>32$ $\left.{ }^{\circ} \mathrm{C}\right)$ and higher salinity (>25,000 ppm) were deleterious to their infection capacity (Brown et al., 2008). Absolute air humidity $(\mathrm{AH})$ modulates AIV survival and transmission, as well as the seasonal occurrence of AIV infection in temperate regions of the globe. $\mathrm{AH}$ has important effects on $\mathrm{AH}$ transmission and livability, and it is more relevant than relative humidity (Shaman \& Kohn, 2009).

AIV frequent interspecific transmission and geographical distribution in wild birds in North America were studied to determine dynamic epidemiological and genetic diversity patterns. Complete AIV sequences were phylogenetically analyzed, taking into account host species, geographical location, and sampling date (Chen \& Holmes, 2009). The demonstration of Eurasian $\mathrm{H} 2$ in North America reinforces the need of continuous epidemiological monitoring of environments shared by migratory routes (Marakova et al., 1999). However, in Italy, no avian to human transmission was detected in avian H5N2 outbreaks (Donatelli et al., 2001). Although the interspecific transmission of Hong Kong H5N1 strains of 1997 was partially aborted, preventing the immediate pandemics scale despite the human casualties (Shortridge et al., 1998), the continued circulation of H5N1 strains in continental China and their reemergence by 2002 was not avoided.

From March to December 1999, 199 LPAIV H7N1 outbreaks occurred in Italy (Veneto and Lombardy, northern Italy). However, by December 1999, a HPAIV 
strain caused $100 \%$ mortality in turkeys within $72 \mathrm{~h}$, and was spread to chickens, Guinea fowl, quails, pheasants, ducks and ostriches, with 413 outbreaks and more than 13 million birds affected. Virus isolation and serology of 759 human sera were negative for theH7 subtype. Evidences suggest the possibility of an undetectable mutation, recommending the eradication of LPAIV H7 and H5 strains (Capua et al., 2002).

\section{Brazilian scenario}

The latest edition of the National Poultry Health Program (PNSA) manual for the contingency of avian influenza and Newcastle disease was published in 2009 (Brasil, 2009) and determines the strategies for preparedness. No occurrence of HPAIV is reported in domestic or wild birds in Brazil. However, a few studies were published regarding LPAIV in Brazilian native fauna and exotic resident avian species. An AIV combat simulation was performed in airports. For active surveillance, a hired actor, interpreting a passenger arriving from China and simulating an acute respiratory disease, travelling from Brasília to Salvador, with stops, tested airport services in Salvador (Anvisa, 2007).

More recently in Brazil, 1,323 normal birds were sampled, being 981 (74.2\%) of order Anseriformes, out of which 884 were of the species Cairina moschata (domestic duck), 185 (14\%) of the Galliformes order (Gallus gallus domesticus, Meleagris gallopavo and Numida meleagris), 67 (5\%) were Sphenisciformes (Spheniscus magellanicus), and the remaining species belonged to the orders orders Charadriiformes and Passeriformes. Samplings were carried out in areas of migratory bird routes in the states of Rondônia, Pará, Maranhão, Pernambuco, São Paulo and Santa Catarina. Samples were tested by RT-PCR or GeneScan. Results allowed the detection of LPAIV in 7/884 (0.1\%) Cairina moschata (domestic duck), one individual Sterna hirundo (common tern) and 2/111 (0.2\%) Gallus gallus domesticus, all in the state of Pará. AIV was also detected in 7/67 (0.1\%) Spheniscus magellanicus (Magellan penguin) from the Aquariums of Santos and Guarujá, state of São Paulo (Golono, 2009).

\section{Patogenicity}

HPAIV strains may cause high morbidity and mortality in most domestic avian species, but may present different pathobiologies, depending on the strain and host species. The emerging $\mathrm{H} 5$ and $\mathrm{H} 7$
HPAIV have shown to be highly virulent to chickens and to have a short incubation period in inoculated embryos. In ducks, the symptoms caused by the Eurasian strains have changed from mild respiratory signs to viremia, visceral and central nervous system (CNS) infection, severe respiratory signs and low fecal transmission. High lethality was demonstrated in young ducks, with cardiac and CNS infection. However, infected ducks excrete only $1 \%$ of the titer excreted by infected chickens (Swayne \& PantinKackwood, 2006). The phylogenetic analyses of duck pathogenic strains have not shown changes in genes associated to pathogenicity, but in other genes (Pantin-Jackwood et al., 2007). The sequential subtypic infections in natural reservoir species were analyzed, showing that the homosubtypic immunity protected birds from clinical expression and greatly reduced virus excretion. However, the hetosubtypic immunity only partially reduced both. The heterosubtypic immunity in reservoir birds ensures clinical protection despite enabling transmission (Fereidouni et al., 2009).

Nigerian HPAIV strains were isolated, characterized and placed in clade 2.2.2. Chicken-challenge (intranasal and intravenous) experiments resulted in systemic disease, with tropism to the endothelium, with necrosis and inflammation of the brain and lungs (Aiki-Raji et al., 2008).

In chickens and turkeys, the incubation period may vary between 3 and 7 days, after which there may be sudden death; severe depression; ruffled feathers; lack of appetite; severe drop in egg production; edema and cyanosis of the head, neck, comb and wattle; petechial hemorrhages in serosa membranes; excessive thirst; watery diarrhea with greenish to whitish color; edema and congestion of the conjunctiva, with occasional hemorrhage; feet and heel skin diffuse hemorrhages; tracheal rales; and nasal and ocular discharge. In turkeys, the symptoms are similar to chickens, and also present sinusitis, variable respiratory mucus accumulation, loss of energy, coughing and sneezing, incoordination, nervous signs such as paralysis, egg production cessation; eggs laid immediately post infection may have weak shells and deformities, surviving birds may be weak and return to lay may take several weeks. Mortality in chickens and turkeys may reach $100 \%$, and death frequently occurs $48 \mathrm{~h}$ after the clinical signs appear; however, it may also occur without any previous clinical signs and may extend to one week after the start of the clinical signs. In turkeys, it may occur between 3 and 10 days. In ducks and geese, the incubation period is similar to 
that of chickens and turkeys (3 - 7 days), with signs of depression, lack of appetite and diarrhea as with laying chickens, edema of the paranasal sinuses, neurological signs in young birds, drop in egg production, and sudden death. Surviving birds may be weak and return to lay may take several weeks. Mortality in ducks and geese may reach 100\% (Swayne \& Halvorson, 2008; Capua et al., 2002; OIE, 2012b).

\section{Diagnosis}

In Brazil, the diagnosis and characterization of AIV is officially performed by the Reference Animal Laboratory (Laboratório de Referência Animal) in Campinas, São Paulo. European Reference Laboratories tasks established for 2010 were presented by the European Community at the $15^{\text {th }}$ Joint Annual Meeting of avian influenza and Newcastle disease (Pittman, 2009).

Influenza control is dependent on and must be based on rapid diagnosis. This is routinely made using conventional reverse transcriptase-PCR or quantitative RT (real time)-PCR, and strains are characterized by product sequencing. Large numbers of samples may be rapidly scanned using the restriction fragment mass fingerprinting (RFMF) of isolates. Three RFMF markers enabled identifying $\mathrm{H} 5 \mathrm{~N} 1$, with a possibility of strain differentiation (Michaela et al., 2009). A laboratory model for virulence typing was proposed in mice, for the 28 North American wild avian strains of subtypes $\mathrm{H} 2, \mathrm{H} 3, \mathrm{H} 4, \mathrm{H} 6, \mathrm{H} 7$ and $\mathrm{H} 11$, demonstrating lesions without the necessity of adaptation and with minimal morbidity (Driskell et al., 2010). AIV preferential cellular infection was determined as based on galactose with $\alpha 2,3$ (avian cells) or $\alpha 2,6$ (human cells) links in sialic acid receptors, using sialidase from Salmonella Thyphimurium to destroy $\alpha 2,3$ galactose links, with diagnosis of $\alpha 2,6$ preference for enabled strains or $\alpha 2,3$ preference for disabled strains (Suptawiwata et al., 2008). Equine red blood cells were proposed for hemagglutination inhibition assays for AIV variant strains that present less affinity to chicken erythrocytes (Jia et al., 2008).

A rapid agglutination test was proposed for the detection of influenza A H1N1 during the pandemics of 2009, with evaluation of forty AIV strains isolated from five different host species. Sensitivity was $88 \%$ for both bird and human strains, and specificity was 99.3\% for human strains and $99.5 \%$ for avian strains (Chen et al., 2010).

Universal PCR assays for the $M$ and NS genes, or specific for $\mathrm{H} 5$ or $\mathrm{H} 7$, have been proposed for the rapid detection of AIV in humans, and were positively correlated with viral isolation, antibody detection, immunohistochemistry and hybridization in nitrocellulose (Pisareva et al., 1992). Laboratory tests are essential for the definitive diagnosis of respiratory diseases, with virological assays for rapid identification, such as multiplex PCR, which has been of great interest. A multiplex reaction with primers directed to the conserved regions of the nucleoprotein gene of AIV $A, B$ or $C$, to the fusion protein of RSV and to the gene encoding the adenovirus exon protein has been described. The amplicons of influenza A, B and $C$ were identified, as well as other products, due to differences in molecular size (Palese \& Shaw, 2007). The PCR-enzyme immunoassay (PCR-EIA) was developed for the identification of influenza A matrix RNA in clinical samples negative for cultivable virus (Starick et al., 2000). A fluorogenic PCR, currently known as realtime $P C R$, for typing and subtyping of respiratory AIV strains was described, using the probe technology that exploits the endogenous nuclease activity of $5^{\prime}-3^{\prime}$ of Taq DNA polymerase and that allows the detection of the amplicon by the release of a fluorescent reagent during PCR reaction (Schweiger et al., 2000). The detection of influenza $A$ was obtained by PCR amplification of conserved sequences of the matrix gene. PCR was faster and 100 times more sensitive than the classical isolation procedures (Fouchier et al., 2000). Two real-time PCR protocols have been described for the detection of matrix gene of the influenza A virus using fluorogenic hydrolysis probes (Spackman et al., 2002), one detecting 10 fentograms ( $\mathrm{fg}$ ) of RNA $(1,000$ copies) and $0.150 \%$ lethal dosis, and hemagglutinin $\mathrm{H} 5$ and $\mathrm{H7}$, detecting $100 \mathrm{fg}$ and 1,000/10,000 RNA copies. For instance, for the detection of AIV H5 and for monitoring viral load (real-time PCR), from 0.05 to 0.10 embryo infectious dose $50 \%\left(\mathrm{DIE}_{50}\right)$ are required, in contrast with a minimum of $3 \mathrm{DIE}_{50}$ in conventional PCR (primers proposed by WHO) and $10 \mathrm{DIE}_{50}$ for the antigen capture ELISA. Known infected pharyngeal swabs ( $n=35)$ from sick birds showed 33 positive birds by real-time PCR, compared with 27,13 and 19 positive detected by conventional PCR, capture ELISA and virus isolation, respectively. Sixty human samples (throat swabs) infected with AIV H1 were negative and sixteen other heterologous viruses used as negative controls were negative (Chen et al., 2007) using RT-PCR. Real-time PCR of CDNA transcribed from AIV RNA was recommended by the CDC (Centers for Disease Control and Prevention, USA) for the rapid identification of AIV subtypes of influenza surveillance 
in humans. The clinical study of the patients must meet the criterion of "influenza-like illness", that is, temperature above $37.8^{\circ} \mathrm{C}$, cough and / or sore throat, no diagnosis of another etiology, hospitalized patients presenting this condition and tested negative by fast tests (kits), or patients who died and presented clinical signs (CDC, 2010). The Food and Drug Administration (FDA) published the authorized in-vitro tests for the disease (FDA, 2010).

Three semi-nested multiplex RT-PCR were developed for the simultaneous detection of twelve respiratory viruses, including influenza $A, B$ and $C$, human respiratory syncytial virus (HRSV), human metapneumovirus (HMPV), parainfluenza virus types 1-4 (PIV-1, -2, -3 and -4), human coronavirus OC43 and 229E (HCoV), and human rhinovirus (HRV). Two hundred and three nasal aspirates of hospitalized children were retrospectively studied by semi-nested multiplex PCR, immunofluorescence and virus isolation, with an overall sensitivity of $98 \%$ (Bellau-Pujol et al., 2005). A RT-nested-PCR methodology was adopted for the detection of AIV as the standard method by the National Standards Unit, Department for Evaluations, Standards and Training, National Public Health of Wales (Metodo Nazionale Standard, 2009).

\section{Training for diagnosis and epidemiologic surveillance}

In response to the HPAIV pandemics, several developing countries have improved their animal health public services, with greater budgets, better laboratories and trained personnel in collaboration with international institutions. A basic laboratory, with two technicians, equipment and reagents would cost about US\$ 500,000 (Sims, 2006). In Hong Kong, the new laboratory to face the influenza outbreaks and other avian diseases cost US\$ 6.1 million (Hinricks et al., 2006).The improvement of six laboratories in Nigeria - one capable for complete diagnosis and five for rapid triage, cost US\$ 3.12 million (Nigeria, 2005), and expenses to improve veterinary services reached US\$10 million. In five years in Viet Nam, the same period as for Nigeria, expenses reached US\$ 30 million (OIE, 2007). Laboratory maintenance and reagent costs in the developing countries of Southeast Asia reached US\$ 0.50-1.50 for serology and US\$10 e 20 for real-time PCR per sample. In Malaysia, surveillance costs were US\$ 533,000 in 2005 (APHCA, 2005). In Hong Kong, surveillance costs per live bird commercialized was US $\$ 0.12 /$ bird or about $6 \%$ of bird price (Health, 2004).

\section{PREVENTION AND CONTROL}

On April 27, 2007, the United States of America Food and Agriculture Administration (FDA) authorized the first HPAIV H5N1 vaccine to humans for the protection of groups at high risk (Skeika \& Jabrb, 2008). The Food and Agriculture Organization of the United Nations published the list of the manufacturers of poultry influenza vaccines (FAO, 2012a). Vaccinations may reduce the risk of infection and lower virus output, with birds representing a lower sanitary risk, and may be used for poultry surrounding outbreaks zones. The three categories of strategies proposed for vaccination by FAO are: (1) Response to an outbreak, employing perifocal vaccination (ring vaccination) or vaccination only of domestic poultry at high risk, in combination with the destruction of infected domestic poultry; (2) Vaccination in response to a "trigger", upon the detection of the disease by surveillance studies, in areas where biosecurity is difficult to be implemented (e.g., high density of poultry farms); and (3) Pre-emptive baseline vaccination of chickens and other avian species when the risk of infection is high and/or the consequences of infection are very serious (FAO, 2012b).

After the influenza outbreaks in poultry and the potential pandemics threat to humans caused by the HPAIV of the H5N1 subtype, improvements in biosecurity and the use of inactivated vaccines are the two main options for the control of the disease. Vaccines against avian influenza are designed to induce the protection of flocks, preventing outbreaks, and can be used as tool in perifocal vaccinations to fight isolated episodes of the disease Although in the United States the control of the HPAIV was obtained by eradication programs, strategies were also employed against the velogenic and mesogenic strains of the Newcastle disease virus (Villegas, 1998). On April 27, 2007, the U.S. Food and Drug Administration (FDA) approved the first vaccine against HPAIV H5N1 for use in humans at high risk of infection (Skeika \& Jabrb, 2007). A model plan for human influenza pandemics preparedness was published in Ireland (A Model..., 2002).

The essence of biosecurity is to minimize the risk of extraneous organisms from entering the premises where poultry are housed, and therefore it is the best strategy to reduce the risk of diseases in general, particularly when poultry are reared in confinement. Ideally, farms should be designed for biosecurity from the beginning. The costs of adaptation may be high and not very cost-effective, as changes in structures, 
equipment and labor management are required. In view of the potential risk represented by freerange chickens in regions where industrial broiler production is practiced, the confinement of the former is recommended. However, investments in biosecurity depend on the risk perception of the farm owner. The estimated cost for improving the quality and the biosecurity of the facilities in intensive and semiintensive poultry production may amount to US\$50.00 for training and may rise to $R \$ 75-100$ per farm for small commercial flocks in Vietnam, Cambodia and Laos. Biosecurity in grandparent stock farms in Viet Nam, including fencing, personnel entry, cloth changing and showering rooms, quarantine facilities, etc., represented US $\$ 57,000$ per farm (Otte et al., 2008a).

Biosecurity norms are published by the Ministry of Agriculture in Brazil (Brasil, 2006, 2009). Interstate transportation is restricted and it is authorized only among states with similar standards of veterinary services. In addition, animal transportation license issued after birds are inspected is required (Brazil, 2006). The Normative Act (NA) No. 56 of December $4^{\text {th }}, 2007$, describes the procedures for the registration, monitoring and control of poultry establishments (Brasil, 2009).

In a few countries, social, economic, geographic and cultural development has increased the risk of $\mathrm{Al}$, as poultry are reared close to natural and potential reservoirs and other domestic species. It has been considered that the highest risk is associated to the proximity to a live infected bird. Therefore, the eradication the disease by destroying infected flocks is an important tool, as it was applied in to control the outbreaks in Italy (Capua \& Marangon, 2000) and China (Wei-Hua, 1998), thereby reducing the time of the impact of the disease. A review article on the prevention of influenza by HPAIV H5N1 in domestic cats was published, although the infection is considered rare and few reports were described in Europe. Notification is mandatory in Europe and suspect cats must be kept in isolation from other cats, birds and other animal species, including humans (Thiry et al., 2009).

AIV can contaminate water sources by the excreta of wild birds or sewage contamination, and therefore treatment processes used by the drinking water industry have been evaluated. The effectiveness of physical treatments (coagulation-flocculationsettling, precipitation by aluminum sulfate, aluminum polychlorosulfate or ferric chloride, hollow fiber membrane ultra-filtration and ultraviolet irradiation) and chemical treatments (monochloramine, chlorine dioxide, chlorine, and ozone) against strains of H5N1 and $\mathrm{H} 1 \mathrm{~N} 1$ viruses was evaluated. Viruses were sprayed onto the water surface and coagulation, flocculationsettling and precipitation were shown to be ineffective in removing infectivity. However, ultra-filtration with hollow fiber reduced $>3$ to $>4 \log 10$ titers. The most effective methods were ultraviolet irradiation at $25 \mathrm{~mJ} /$ $\mathrm{cm}^{2}$, ozone at $0.5 \mathrm{mg} / \mathrm{L}$ e $1 \mathrm{mg} / \mathrm{L} / 10 \mathrm{mi}, \mathrm{n}$ and chlorine dioxide (0.3 to $3 \mathrm{mg} / \mathrm{L}$ (ppm)/5-120min), reducing $>5 \log 10$ titers. Monochloroamine was the least efficient method (Lénès et al., 2010).

Recommendations for the disposal and disinfection of contaminated material have been published. The use of gloves, eye protection and disposable clothing for disposing of carcasses by burning or burying, cleaning animal housing facilities and equipment, such as cages, with detergent in water (10 min.), or sodium hypochlorite (liquid) at 2-3\% available chlorine / 10-30 min are recommended. Citric acid is safe for clothes and body decontamination at $2 \mathrm{~g} /$ liter $(0.2 \%)$, with contact for at least 30 minutes. Electrical equipment may be disinfected by formaldehyde gas for 15-24 hours. For human skin (hands, face and other exposed skin), the use of soaps and detergents for at least 10 minutes is recommended (FAO, 2012c).

Registered antiseptic products in the USA for influenza A disinfection were recommended for non-porous surfaces and considered effective against AIV. EPA publishes the antimicrobial pesticide product fact sheet updates (EPA, 2007). Cleaning with detergent or soap is the first step for removing the surface contamination and may be followed by the application of disinfectants (USC, 2011). Disinfection and sterilization of healthcare facilities were proposed by the Health Care Advisory Committee (CDC-Center for Disease Control, Department of Health and Human Services, USA), for settings such as hospitals, out-patient care and home care (Rutala et al., 2008), reviewing the CDC guidelines of 1985, and proposing as first step thorough cleaning for the removal of organic and inorganic matter for the best efficiency of chemical disinfection.

Seasonal influenza vaccines in humans were primarily developed to induce protection in elderly and immune-compromised people, preventing the severe effects on these hosts. Global production capacity for seasonal influenza vaccines is $\mathbf{3 5 0}$ million doses of trivalent-inactivated vaccine, with estimated possible 2-3 year expansion to 780 million doses, and up to 2.3 billion doses by 2009 . The nine industrial 
countries capable of producing the vaccine are Australia, Canada, France, Germany, Italy, Japan, The Netherlands, United Kingdom and USA. The Strategic Advisory Group of Experts on Immunization (SAGE) suggests that current data on vaccines indicate that these are safe, immunogenic at lower doses, and cross-protective against $\mathrm{H} 5 \mathrm{~N} 1$ strains. Developed countries may require a 3-6 months interval to prepare novel human influenza vaccines, which may not be available for poorer countries and poorer countries may possibly lack the vaccine. Short-term stockpiling is recommended for the control of early outbreaks, as well as vaccinating key public health personnel and longterm partnerships for local vaccine production (WHO, 2006). The research on human vaccines includes the development of mass vaccination strategies.

Using reverse genetics, temperature-sensitive mutations were introduced in PB1 and PB2 genes and further changes in NA for HA gene. In 2-weekold chickens, the infection with a H7N2/att strain provided complete protection against LPAIV H7N2. A new generation of attenuated H5N1/att strain was developed for mass vaccination, inoculated in ovo at 18 days of incubation, resulting in $60 \%$ protection of 4 -week-old chickens and $100 \%$ protection of 9 to 12 -week-old chickens, and no challenge virus was detected post-challenge (Song et al., 2007).

Live attenuated cold-adapted $\mathrm{H} 5 \mathrm{~N} 1$ vaccines were developed for ferrets (Jina et al., 2007). The attenuating mutations specified by the $\mathrm{AA}$ ca loci had the greatest influence; the deletion of the $\mathrm{H} 5 \mathrm{HA}$ multi-basic cleavage site (MBS) was next in importance; and the AA genes acting in concert with the H5N1 glycoproteins caused a constellation of effects for a recombinant live attenuated virus $\triangle \mathrm{H} 5 \mathrm{~N} 1$ with modified hemagglutinin ( $\mathrm{HA}$ ) and intact neuraminidase genes (Suguitan et al, 2009). A set of experimental live attenuated vaccine strains based on a recombinant H5N1 influenza virus ANiet Nam/1203/04, lacking the polybasic cleavage site by reverse genetics, but with full-length or a C-terminally truncated NS1 protein, protected mice and chickens from lethal homologous challenge, with high level of protection against a heterologous virus (Steel et al., 2009). A chimeric dual specificity H5N1 virus, expressing the HN ectodomain of an apathogenic Newcastle disease virus (NDV) strain but not the influenza NA gene, enhanced the entry of foreign proteins into virus particles, while a bivalent strain, expressing the H7 HA on NDV background, resulted in $90 \%$ protection against HPAIV and $100 \%$ protection against NDV challenges (Park et al., 2006).
Inactivated Al vaccines should be given by injection, as demonstrated for conventional inactivated homologous or heterologous HA virus, both with heterologous NA, in order to enable the differentiation from the circulating virus through the DIVA strategy (differentiating infected from vaccinated animals), and were successfully used in Italy (Capua \& Marangon, 2006), although in Mexico they were questioned for the possible induction of selective pressure (Lee et al., 2004; Webster et al., 2006). After fatal infections by HPAIV H5N1 in Falconiformes, ten hawks were vaccinated with an inactivated $\mathrm{H} 5 \mathrm{~N} 2$, which was considered protective and reduced transmission (Lierz et al., 2007). A Vero cell culture of the H5N1 virus was highly immunogenic in animal models after inactivation, allowing rapid high yield of a candidate pandemic virus in cell culture (Kistner et al., 2007). Current H5N1 strain vaccine responses may provide the necessary priming in humans to cope with variant HPAIV emerging strains, as determined by a Vero cell grown H5N1 given to mice (Sabartha et al., 2010). Mice were studied as an alternative to eggs to produce influenza human vaccines, considering a possible egg shortage during pandemics (Hoelscher et al., 2006). Several inactivated recombinant vaccines expressing genes encoding protection-inducing proteins were evaluated. Mice given an incompetent adenovirus recombinant vector expressing $\mathrm{H} 5$ ( $\mathrm{Had}-\mathrm{H} 5 \mathrm{NA}$ ) were resistant to homologous and heterologous H5N1 challenge (Hoelscher et al., 2006). However, virus shedding was reported (Sasaki et al., 2009). Employing reverse genetics, one AIV subtype $\mathrm{H} 5$ was constructed for the expression of the ecto-domain of Newcastle disease virus (NDV) HN, instead of N1 (Park et al. , 2006). The intranasal administration of gamma-irradiated, but not formalin- or UV-inactivated A/PR/8/Puerto Rico/8/34 (H1N1), protected mice against mortality after challenge with a HPAIV AVietnam/1203/2004 [H5N1] and other heterologous strains (Furuya et al., 2010).

As the HPAIV H5N1 avian influenza is possibly now endemic in both domestic and migratory birds in Eurasia, eradication alone may not control H5N1 influenza spread. For instance, ducks are not uniformly killed by HPAIV H5N1 viruses and play a major role in virus spread. A reverse genetics-derived $\mathrm{H} 5 \mathrm{~N} 3$ strain inactivated oil-emulsion vaccine provided protection against lethal H5N1 challenge in ducks, but two doses were required to protect chickens (Webster et al., 2006). Using plasmid-based reverse genetics, a transfectant H5N1/PR8 virus was generated, with the multibasic 
amino acid motif removed. The transfectant H5N1/PR8 was attenuated for chickens and mice with no loss of immunogenicity, inducing protection against HPAIV H5N1 challenge in mice (Subbarao et al., 2003). The deletion of the non-essential ULO gene of the infectious laryngotracheitis virus (ILTV) led to its attenuation in chickens. Vaccination with ULO mutants, expressing influenza virus haemagglutinin $(\mathrm{H} 7)$, protected chickens against ILT and homologous fowl plague, although it di not protect against H5N1, despite its long survival time (Veits et al., 2003). The protection of chickens against HPAIV H5N1 infection was achieved by vaccination with recombinant live ILTV, expressing H5 hemagglutinin or/and N1 neuraminidase (H5-ILTV). Chickens vaccinated with the H5-ILTV expressed limited infection post-H5N1 challenge, as detected by RT-PCR, and the limited infection of challenge virus was blocked by a secondary vaccination with N1-ILTV. The absence of antibodies against AIV nucleoprotein in recombinant virus response enables the differentiation between vaccination and challenge responses (Pavlova et al., 2009).

The vaccination of poultry against HPAIV is a control measure in endemic regions and may be important in eradication programs, in order to prevent the destruction of large numbers of flocks, to reduce the number of outbreaks and the circulation of virus in a country or region, or also to be used as insurance against economic losses resulting from outbreaks. Official mass vaccination campaigns of poultry against HPAl have been conducted in several countries, including Hong Kong, China, Viet Nam, Indonesia, Egypt, Côte d'Ivoire, Pakistan and Mexico. In Viet Nam, mass vaccination campaigns under the supervision of public veterinary services are conducted twice a year. Investments were made in cold storage for vaccines, training of vaccinators, and mass communication campaigns. The total investment of delivering 364.5 million vaccine doses during the first year of the campaign was estimated in approximately US\$21 million or US\$0.06 per bird vaccinated. In Côte d'Ivoire, the cost of delivering 31.8 million vaccines during the first year of the campaign was estimated in US $\$ 2.25$ million or approximately US\$0.07 per bird (Otte et al., 2008a).

The development of a vaccine strain before pandemics occur, using for instance, reverse genetics re-assortment of H5N1 Anhui/PR8 virus, without the multi-basic HA cleavage motif, may be suitable for vaccine production against H5N1 clade 2.3-4 viruses occurring in China, Viet Nam, Thailand and Laos (Dong et al., 2009). A/Puerto Rico/8/34 (H1N1) reverse genetics re-assortants were produced in Vero and chicken embryo cells, maintaining their original internal proteins and exhibiting envelope proteins of the non-pathogenic strains, had their safety tested in ferrets and chickens (Lagastelois et al., 2007).

The degree of protection against HPAIV H5 viruses was shown to be dependent on the homology of $\mathrm{H} 5$ vaccine and the sequences of the challenge viruses. Protection may be provided against homologous challenges, but only partially against heterologous challenges (Römer et al., 2008). Inter-pandemic strains may present minor genetic changes, which result in antigenic drift, evolving by host selection to antigenic shift, if conditions are favorable. Epidemiological monitoring is the basis for determining the necessity of vaccine updating and which antiviral drug should be recommended (De Jong et al., 2000).

\section{REFERENCES}

A model plan for influenza pandemic preparedness. Version 5.2, 2002 [cited 2012 Abr 06]. Available from: http://www.fao.org/docs/eims/ upload//221474/national_plan_ai_irl_en.pdf.

Aiki-Raji CO, Aguilar PV, Kwon YK, Goetz S, Suarez DL, Jethra Al, et al. Phylogenetics and pathogenesis of early avian influenza viruses (H5N1), Nigeria. Emerging Infectious Diseases 2008; 14(11):1753-1755.

Alam J, Akteruzzaman M, Ataur RSM, Salahuddin PM. Impact of recent outbreak of avian influenza on production, marketing and consumption of poultry meat and eggs in Bangladesh. Savar: Bangladesh Livestock Research Institute; 2008.

Alexander DJ, Brown $\mathrm{IH}$. History of highly pathogenic avian influenza. Revue Scientifique et Technique: International Office of Epizootics 2009;28(1): 19-38.

Anvisa. Simulado de influenza aviária envolve três estados [cited 2012 abr 06]. Notícias Anvisa, 27 jun 2007. Available from: http://www.anvisa. gov.br/divulga/noticias/2007/270607_1.htm\#.

APHCA. Report of the twenty-ninth session of the animal production and health. Bali, Indonésia: FAO RAP; 2005; p.133. (Publication 2006/02).

Assessment of the 2009 Influenza A (H1N1) Pandemic on selected countries in the southern hemisphere: Argentina, Australia, Chile, New Zealand and Uruguay [cited 2012 March 10]. Available from: http://www.flu. gov/professional/global/final.

Beach RH, Poulos C, Pattanayak SK. Agricultural household response to avian influenza prevention and control policies. Journal of Agricultural and Applied Economics 2007; 39:301-11, 2007.

Bellau-Pujol S, Vabret A, Legrand L, Dina J, Gouarin S, PetitjeanLecherbonnier J, Pozzetto B, et al. Development of three multiplex RTPCR assays for the detection of 12 respiratory RNA viruses. Journal of Virological Methods 2005; 126(1-2):53-63.

Biswas SK, Nayak DP. Mutational analysis of the conserved motifs of influenza A virus polymerase basic protein 1. Journal of Virology 1994; 68(3):1819-1826

Brasil. Instrução normativa n 59, de 02 de dezembro de 2009 [cited 2010 April 21]. Available from: http://www.agricultura.gov.br/.

Brasil. Ministério da Agricultura, Secretaria de Defesa Agropecuária Instrução Normativa No 17, de 7 de abril de 2006 [cited 2010 April 21]. Available from: http://www.agricultura.gov.br/.

Brasil. Ministério da Saúde. Informe Técnico Campanha Nacional de Vacinação Contra a Influenza 2011 [cited 2010 april 21]. Available from: http://portal.saude.gov.br/portal/arquivos/pdf/informe_campanha_ influenza_2011.pdf.

Brown JD, Goekjian G, Poulson R, Valeika S, Stallknecht, DE. Avian influenza virus in water: Infectivity is dependent on $\mathrm{pH}$, salinity and temperature. Veterinary Microbiology 2009; 136(1-2):20-26. 
Brydon EW, Morris SJ, Sweet C. Role of apoptosis and cytokines in influenza virus morbidity. FEMS Microbiology Reviews 2005;29(4):837-850

Capua I, Marangon, S. The avian influenza epidemic in Italy, 1999-2000: A review. Avian Pathology 2000; 29:289-294.

Capua I, Mutinelli F, Pozza, D, Donatelli M, Puzelli IS, Cancellotti MF. The 1999-2000 avian influenza (H7N1) epidemic in Italy: veterinary and human health implications. Acta Tropica 2002; 83(1):7-11

Cauthern AN, Swayne, DE, Schultz-Cherry, S, Perdue, ML, Suarez, DL. Continued circulation in China of highly pathogenic avian influenza viruses encoding the hemagglutinin gene associated with the 1997 H5N1 outbreak in poultry and humans. Journal of Virology 2000; 74(14): 6592-6599.

CDC - Centers for Disease Control and Prevention 1600 Clifton Rd. Atlanta, GA, 30333, USA [cited 2010a Nov 27]. Available from: http://www. cdc.gov/h1n1flu/screening.htm.

CDC - Centers for disease control and prevention 2009 H1N1 Flu: international situation update [cited 2010c june 03]. Available from: http://www.cdc.gov/h1n1flu/updates/international/.

CDC - Centers for disease control and prevention. 2009 H1N1 Flu: situation update [cited 2010b Jun 03]. Available from: http://www.cdc.gov/ h1n1flu/update.htm.

CDC - Centers for Disease Control and Prevention. Update: influenza activity-United States and worldwide, May 20-September 15, 2007. MMWR Morbidity and Mortality Weekly Report 2007; 56:1001-4.

Chakma D. Rapid assessment on socio-economic impact due to highly pathogenic avian influenza in Bangladesh. Report submitted to FAO; 2008. p.35.

Chaojian S. Economics of HPAl prevention strategies within the Chinese poultry sector. In: Social and Economic Impacts of Avian Influenza Control. FAO Workshop Proceedings; 2004; Bangkok. Thailand. p.1925

Chen $\mathrm{R}$, Holmes EC. Frequent inter-species transmission and geographic subdivision in avian influenza viruses from wild birds. Virology 2009; 383(1):156-161

Chen W, He B Li C, Zhang X, Wu W, Yin X. Real-time RT-PCR for H5N1 avian influenza A virus Detection. Journal of Medical Microbiology 2007; 56, 603-607.

Chen Y, Xu F, Gui X, Yang K, Wu X, Zheng Q. A rapid test for the detection of influenza A virus including pandemic influenza A/H1N1 2009. Journal of Virological Methods 2010; 167(1):100-102

Coiras MT, Pérez-Breña P, García ML, Casas I. Simultaneous detection of influenza $A, B$, and $C$ viruses, respiratory syncytial virus, and adenoviruses in clinical samples by multiplex reverse transcription nested-PCR assay. Journal of Medicine Virology 2003; 69(1):132-44.

Condit RC. Principles of virology. In: Knipe DM, Howley PM. Fields virology. $5^{\text {th }}$ ed. Philadelphia: Lippincott Williams \& Wilkins; 2007.

Cost of avian influenza control: DLD Perspectives. In: Social and Economic Impacts of Avian Influenza Control. FAO Workshop Proceedings; 2004; Bangkok. Thailand. p. 39-40.

Cros JF, Garcia-Sastre A, Palese P. An unconventional NLS is critical for the nuclear import of the influenza $A$ virus nucleoprotein and ribonucleoprotein. Traffic 2005; 6(3):205-213.

Dawood FS, Jain S, Finelli L, Shaw MW, Lindstrom S, Garten RJ, Gubareva LV, Xu X, Bridges, CB, Uyeki TM. Emergence of a novel swine-origin influenza $A$ (H1N1) virus in humans. New England Journal of Medicine 2009; 360:2605-2615

De Jong JC, Rimmelzwaan GF, Fouchier RA, Osterhaus AD. Influenza virus: a master of metamorphosis. Journal of Infection 2000; 40:218-228.

Donatelli I, Campitelli L, Di Trani L, Puzelli S, Selli L, Fioretti A, et al. Characterization of H5N2 influenza viruses from Italian poultry. Journal of General Virology 2001; 82:623-630.

Dong J, Matsuoka Y, Maines TR, Swayne DE, O'Neill E, Davis CT, et al. Development of a new candidate H5N1 avian influenza virus for pre-pandemic vaccine production. Journal of Influenza and Other Respiratory Viruses 2009; 3(6):287-295.

Driskell EA, Jones CA, Stallknecht DE, Howerth EW, Tompkins SM. Avian influenza virus isolates from wild birds replicate and cause disease in a mouse model of infection. Virology 2010; 399(2):280-289.

Earp LJ, Delos SE, Park HE, White, GM. The many mechanisms of viral membrane fusion proteins. Current Topics of Microbiology and Immunology 2005;285:25-66.
Eigen M, McCaskill J, Schuster P. Molecular quasi-species. Journal of Physical Chemistry 1998; 92(24):6881-6891.

Engelhardt OG, Smith M, Fodor E. Association of the influenza A virus RNAdependent RNA polymerase with cellular RNA polymerase II. Journal of Virology 2005;79(9):5812-5818.

Enstone JE, Myles PR, Openshaw PJM, Gadd EM, Lim WS, Semple MS, et al. Nosocomial pandemic (H1N1) 2009 United Kingdom, 2009-2010. Emerging Infectious Diseases 2011; 17(4); 592-8.

EPA. U.S. Environmental Protection Agency. Registered antimicrobial products with label claims for avian (bird) flu disinfectants. 2007 [cited 2012 Mar 13]. Available from: http://www.epa.gov/pesticides/ factsheets/avian_flu_products.htm.

European Commission, Health \& Consumer Protection Directorate-General, Directorate C - Scientific Health Opinions, Unit C3 - Management of scientific committees II, The Definition of Avian Influenza, The use of Vaccination against Avian Influenza, Scientific Committee on Animal Health and Animal Welfare, Adopted 27 June 2000 [cited 2010 Jun 4] Available from: http://ec.europa.eu/food/fs/sc/scah/out45-final en.pdf

FAO - Food and Agriculture Organization. Avian influenza vaccine producers and suppliers for poultry; 2009 [cited 2012a April 06]. Available from: ftp://ftp.fao.org/docrep/fao/011/ai326e/ai326e00.pdf.

FAO - FAO Recommendations on the Prevention, Control and Eradication of Highly Pathogenic Avian Influenza (HPAI) in Asia, September 2004 [cited 2012b April 06]. Available from: http://www.fao.org/docs/eims/ upload/165186/FAOrecommendationsonHPAl.pdf.

FAO - Food and Agriculture Organization. [cited 2012 Mar 13]. Available from: http://www.fao.org/ avianflu/en/disinfection.html.

FAO -Food and Agriculture Organization. Preparing for highly pathogenic avian influenza, 2007 [cited 2012c april 06]. Available from: ftp://ftp. fao.org/docrep/fao/012/i0808e/i0808e.pdf

Fauquet C, Mayo MA, Maniloff J, Desselberger U, Ball LA, editors. Virus vaxonomy: VIIIth Report of the International Committee on Taxonomy of Viruses. London: Elsevier Academic Press; 2004

FDA - US Food and Drug Administration. Medical devices and flu emergencies 2010 [cited 2012 April 06]. Available from: http://www. fda.gov/MedicalDevices/Safety/EmergencySituations/ucm161496.htm.

Fereidouni SR, Starick E, Beer M, Wilking H, Kalthoff D, Grund C, et al. Highly pathogenic avian influenza virus infection of mallards with homo- and heterosubtypic immunity induced by low pathogenic avian influenza viruses. PLoS ONE 2009; 4(8): 6706 [cited 2012 April 16]. Available from: http://www.ncbi.nlm.nih.gov/pmc/articles/PMC2724736/pdf/ pone.0006706.pdf

Ferko B, Stasakova J, Romanova J, Kittel C, Sereinig S., Katinger H, Egorov A. Immunogenicity and protection efficacy of replication-deficient influenza A viruses with altered NS1 genes. Journal of Virology 2004; 78(23):13037-13045

Fiers W, De Filette M, Birkett A, Neirynck S, Min Jou W. A universal human influenza A vaccine. Virus Research 2004; 103(1-2):173-176

Fouchier RAM, Bestebroer TM, Herfst S, van der Kemp L, Rimmelzwaan GF, Osterhaus ADME. Detection of Influenza A viruses from different species by PCR amplification of conserved sequences in the matrix gene. Journal of Clinical Microbiology 2000; 38 (1): 4096-4101.

Franciosi C, D'Aprile PN, Alexander DJ, Petek M. Influenza virus infections in commercial turkeys in North East Italy. Avian Pathology 1981;10: 303-311.

Fraser C, Donnelly, CA, Cauchemez, S, Hanage, WP, Van Kerkhove, MD, Hollingsworth, TD, et al. Rapid Pandemic Assessment Collaboration. Pandemic potential of a strain of influenza A (H1N1): Early findings. Science 2009; 324 (5934): 1557-1561

Furuya Y, Regner M, Lobigs M, Koskinen A, Mullbacher A, Alsharifi M. The effect of inactivation method on the cross-protective immunity induced by whole 'killed' influenza A viruses and commercial vaccine preparations. Journal of General Virology 2010;91:1450-1460.

Gabriel G, Herwig A, Klenk H D. Interaction of polymerase subunit PB2 and NP with importin alpha1 is a determinant of host range of influenza A virus. PLoS Pathology 2008; 4: e11 [cited 2010 May 10]. Available from: http://www.ncbi.n/m.nih.gov/pmc/articles/PMC2222953/pdf / ppat.0040011.pdf.

Garcia-Sastre A. Inhibition of interferon-mediated antiviral responses by influenza A viruses and other negative-strand RNA viruses. Virology 2001;279:375-384. 
Garten RJ, Davis CT, Russell CA, Shu B, Lindstrom S, Balish Al, et al. Antigenic and genetic characteristics of swine-origin 2009 A (H1N1) influenza viruses circulating in humans. Science 2009; 325:197-201.

Golono MA. Epidemiologia e caracterização molecular de virus da influenza em aves residents e migratórias no Brasil [tese]. São Paulo (SP): Universidade de São Paulo; 2009. 102 p

Health Welfare and Food Bureau Prevention of Avian Influenza. Prevention of avian influenza: consultation on long term direction to minimize the risk of human infection. The Government of Hong Kong Special Administrative Region; 2004. p.45

Hinrichs J, Sims L, McLeod A. Some direct costs of control for avian influenza. Proceedings of the $11^{\text {th }}$ International Society for Veterinary Epidemiology and Economics; 2006 [cited 2010 May 10]. Available from: http://www.sciquest.org.nz.

Hoehling AA. The great epidemic. Boston: Little Brown \& Co; 1961

Hoelscher MA, Garg S, Bangari DS, Belser JA, Lu X, Stephenson I, et al. Development of adenoviral-vector-based pandemic influenza vaccine against antigenically distinct human $\mathrm{H} 5 \mathrm{~N} 1$ strains in mice. The Lancet 2006; 367(9509):475-481

Horimoto T, Kawaoka $Y$, Pandemic threat posed by avian influenza A viruses. Clinical Microbiology Reviews 2001; 14: 129-149.

Ibrahim A, Albrechtsen L, Upton M, Morgan N, Rushton J. Market impacts of HPAl outbreaks: a rapid appraisal process Egypt [Report submitted to FAO]; 2007. p.33.

Jackson S, Van Hoeven N, Chen LM, Maines TR, Cox NJ, Katz JM, Donis RO. Reassortment between avian H5N1 and human H3N2 influenza viruses in ferrets: A public health risk assessment. Journal of Virology 2009; 83(16): 8131-8140

Jia N, Wangb S-X, Liud Y-X, Zhanga P-H, Zuoa S-Q, Zhana L, et al. Increased sensitivity for detecting avian influenza-specific antibodies by a modified hemagglutination inhibition assay using horse erythrocytes. Journal of Virological Methods 2008; 153:43-48.

Jin $\mathrm{H}$, Manetz S, Leininger JC, Lukec, Subbarao K, Murphy B, et al. Toxicological evaluation of live attenuated, cold-adapted $\mathrm{H} 5 \mathrm{~N} 1$ vaccines in ferrets. Vaccine 2007; 25(52): 8664-8672

Joint Fourteenth Annual Meetings of the National Laboratories for Avian Influenza and Newcastle Disease of European Union Member States. Proceedings of Joint Fourteenth Annual Meetings of the National Laboratories for Avian Influenza and Newcastle Disease of European Union Member States. Conference Centre Albert Borschette; 2008; Brussels. Belgium.

Katz JM, Veguilla V, BelserJA, Maines TR, Van Hoeven N, Pappas NC, et al. The public health impact of avian influenza viruses. Poultry Science 2009:88:872-879.

Kendal AP, Goldfield M, Noble GR, Dowdle WR. Identification and preliminary antigenic analysis of swine influenza-like viruses isolated during an influenza outbreak at Fort Dix, New Jersey. Journal of Infectious Diseases 1997; 136 (suppl): 381-385.

Kilbourne ED, Pokorny BA, Johansson B, Brett I, Milev Y, Matthews JT. Protection of mice with recombinant influenza virus neuraminidase. Journal of Infectious Diseases 2004; 189(3):459-461.

Kim HR, Park CK, Lee YJ, Woo GH, Lee KK, Oema JK, et al. An outbreak of highly pathogenic H5N1 avian influenza in Korea, 2008. Veterinary Microbiology 2009;141(3-4): 362-366.

Kiso M, Mitamura K, Sakai-Tagawa Y, Shiraishi K, Kawakami C, Kimura K, et al. Resistant influenza A viruses in children treated with oseltamivir: descriptive study. Lancet 364(9436):759-765.

Kistner O, Howard MK, Spruth M, Wodal W, Brühl P, Gerencer M, Crowe BA, et al. Cell culture (Vero) derived whole virus (H5N1) vaccine based on wild-type virus strain induces cross-protective immune responses. Vaccine 2007; 25(32):6028-6036.

Klenk HD, Rott R, Orlich M, Blodorn J. Activation of influenza A viruses by trypsin treatment. Virology $1975 ; 68: 426-439$

Knossow M, Gaudier M, Douglas A, Barrère B., Bizebard T., Barbey C., et al. Mechanism of neutralization of influenza virus infectivity by antibodies. Virology 2002; 302(2):294-298.

Koch G, Elbers ARW. Outdoor ranging of poultry: a major risk factor for the introduction and development of High-Pathogenicity Avian Influenza. Journal of Life Sciences 2006; 54 (2):179-194.

Krauss S, Obert CA, Franks J, Walker D, Jones K, Seiler $\mathrm{P}$, et al. Influenza in migratory birds and evidence of limited intercontinental virus exchange [cited 2012 April 20]. PLoS Pathogens 3(11):e167. Available from: http://www.plospathogens.org.

Lam TY, Pybus OG, Hon CC, Leung FC. Molecular epidemiology of H5N1 Avian Influenza Virus: Correlations between antigenic drift, geographical migration and expansion of viral diversity. Proceedings of the $13^{\text {th }}$ International Congress on Infectious Diseases; 2008; Hong Kong: Beijing International Convention Center; 2008. p. 58-59.

Lamb RA, Parks GD. Paramyxoviridae: The viruses and their replication. In: Knipe DM, Howley PM. Fields virology. 5th ed. Philadelphia: Lippincott Williams \& Wilkins; 2007.

Lee CW, Senne DA, Suarez DL. Effect of vaccine use in the evolution of Mexican lineage H5N2 avian influenza virus. Journal of Virology 2004; 78(15):8372-81

Legastelois I, Garcia-Sastre A, Palese P, Tumpey TM, Maines TR, Katz JM et al. Preparation of genetically engineered $\mathrm{A} / \mathrm{H} 5 \mathrm{~N} 1$ and $\mathrm{A} / \mathrm{H} 7 \mathrm{~N} 1$ pandemic vaccine viruses by reverse genetics in a mixture of vero and chicken embryo cells. Influenza and Other Respiratory Viruses 2007; 1(3):95-104

Lénès $D$, Deboosere $N$, Menard-Szczebara $F$, Jossent J, Alexandre $V$ Machinal C, Vialette M. Assessment of the removal and inactivation of influenza viruses H5N1 and H1N1 by drinking water treatment. Water Research 2010; 44:2473-2486.

Lessler J, Cummings DA, Fishman S, Vora A, Burke DS. Transmissibility of swine flu at Fort Dix, 1976. Journal of Royal Society, Interface/The Royal Society 2007; 4(15):755-762

Li KS, Guan Y, Wang J, Smith GJ, Xu KM, Duan L, et al. Genesis of a highly pathogenic and potentially pandemic H5N1 influenza virus in eastern Asia. Nature 2004; 430:209-213.

Lichtenberg E. Agriculture and the environment. In: Gardner BL, Rausser GC, editors. Handbook of agricultural economics. Amsterdam: Elsevier; 2002

Lierz M, Hafez MH, Klopfleisch R, Lüschow D, Prusas C, Teifke JP, et al. Protection and virus shedding of falcons vaccinated against highly pathogenic Avian Influenza A Virus (H5N1). Emerging Infectious Diseases 2007: 13(11):1667-1674.

Luo C, Nobusawa E, Nakajima K. Analysis of the desialidation process of the haemagglutinin protein of influenza B virus: the host-dependent desialidation step. Jornal of General Virology 2002; 83:1729-1734.

Maines TR, Chen LM, Matsuoka Y, Chen H, Rowe T, Ortin J, Falcón A, et al. Lack of transmission of $\mathrm{H} 5 \mathrm{~N} 1$ avian-human reassortant influenza viruses in a ferret model. Proceedings of the National Academy of Sciences USA 2006; 103(32):12121-12126.

Marakova NV, Kaverin NV, Krauss S, Senne D, Webster R.G. Transmission of Eurasian avian $\mathrm{H} 2$ influenza virus to shore birds in North America. Journal of General Virology 1999; 80: 3167-3171.

Marjuki H, Wernery U, Yen HL, Franks J, Seiler P, Walker D, et al. Isolation of highly pathogenic avian influenza H5N1 virus from Saker falcons (Falco cherrug) in the Middle East. Advances in Virology 2009; doi:10.1155/2009/294520

Marm KA, Chmura AA, Gibbons DW, Fleischer RC, Marra PP, Daszak P. Predicting the global spread of H5N1 avian influenza. Proceedings of the National Academy of Sciences of The United States of America 2006; 103(51):19215-19606.

Martins NRS. Influenza aviária: uma revisão dos últimos dez anos. Revista Brasileira de Ciência Avícola 2001; 3:97-140.

Matrosovich M, Tuzikov A, Bovin N, Gambaryan A, Klimov A, Castrucci MR Donatelli, IKY.Early alterations of the receptor-binding properties of $\mathrm{H} 1$, $\mathrm{H} 2$ and $\mathrm{H} 3$ avian influenza virus hemaglutinins after their introduction into mammals. Journal of Virology 2000; 74: 8502-8512.

Matrosovich MN, Matrosovich TY, Gray T, Roberts NA, and Klenk, HD. Human and avian influenza viruses target different cell types in cultures of human airway epithelium. Proceedings of the National Academy of Sciences USA 2004; 101(13):4620-4624.

McLeod A, Dolberg F, editor. Future of poultry farmers in Viet Nam after HPAI. FAO and MARD Workshop; 2007; Hanoi. p.99.

Messias EL, Cordeiro NF, Sampaio JJ, Bartko JJ, Kirkpatrick B. Schizophrenia and season of birth in a tropical region: relation to rainfall. Schizophrenia Research 2001; 48:227-234.

Metodo Nazionale Standard. Rt-Pcr Per Ricerca Di Virus Ifluenzali A Vsop 42 Emesso da Standards Unit, Department for Evaluations, Standards and Training Centre for Infections [cited 2012 Jul 03]. Available from: http:// fad.italbioforma.it/Sops/vsop42.pdf. 
Michaela K, Harderb TC, Mettenleitera TC, Kargera A. Diagnosis and strain differentiation of avian influenza viruses by restriction fragment mass analysis. Journal of Virological Methods 2009; 158(1-2):63-69, 2009.

Mounts AW, Kwong $\mathrm{H}$, lzureta HS, Ho Y, Lee AT, M., Buxton BC, et al. Case-control study of risk factors for avian influenza $A(H 5 N 1)$ disease, Hong Kong, 1997. Journal of Infectious Diseases 1999; 180:505-508.

Myers KP, Olsen CW, Gray GC. Cases of swine influenza in humans: A review of the literature. Clinical Infectious Diseases 2007; 44:10841088.

NaRanong, V. Structural changes in Thailand's poultry sector and its social implications. Proceedings of the Conference Poultry in the 21st Century, Avian Influenza and Beyond; 2007.

Nayak DP, Hui EK, Barman S. Assembly and budding of influenza virus. Virus Research 2004; 106(2):147-165

Neumann G, Fujii K, Kino Y, and Kawaoka, Y. An improved reverse genetics system for influenza $A$ virus generation and its implications for vaccine production. Proceedings of the National Academy of Sciences USA 2005; 102(46):16825-16829.

Newman AP, Reisdorf E, Beinemann J, Uyeki TM, Balish A, Shu B, et al. Human case of swine influenza $A(\mathrm{H} 1 \mathrm{~N} 1)$ triple reassortant virus infection, Wisconsin. Emerging Infectious Diseases 2008; 14(9):14701472.

Nicita A. Avian influenza and poultry trade. Washington: Development Research Group; 2007. p.23. (Policy Research Working Paper, 4551).

Nigeria Federal Department of Livestock and Pest Control Services. HPAl in Nigeria: strategies for prevention of introduction, disease surveillance networking and contingency plan for a disease emergency. Nigéria: Report of the Technical Committee of Experts on the Prevention and Control of HPAl in Nigeria; 2005.

OIE - International des Epizooties. Avian influenza. World Organization for Animal Health. [cited 2012b March 23]. Available from: http://www. oie.int/fileadmin/Home/eng/Health standards/tahm/2.03.04 Al.pdf.

OIE - Office International des Epizooties. World organization for animal health. Highly pathogenic avian influenza Aetiology epidemiology diagnosis prevention and control references [cited 2012 Jul 03]. Available from: http://www.oie.int/fileadmin/Home/eng/Animal Health_in_the_World/docs/pdf/AVIAN_INFLUENZA_FINAL.pdf.

OIE - Office International des Epizooties. World Organization for Animal Health [cited 2012a Mar 15]. Outbreaks of highly pathogenic avian influenza. Available from: http://www.oie.int/fileadmin/Home/eng/ Animal_Health_in_the_World/docs/pdf/-graph_avian_influenza/ graphs_HPAl_11_03_2012.pdf

OIE - The World Organization for Animal Health. Prevention and control of animal diseases worldwide, economic analysis - prevention versus outbreak costs. Asford: Agra CEAS Consulting; 2007. p. 238.

Olsen CW, Brammer L, Easterday BC, Arden N, Belay E, Baker I, Cox NJ. Serologic evidence of $\mathrm{H} 1$ swine influenza virus infection in swine farm residents and employees. Emerging Infectious Diseases 2002; 8:814819.

Olsen CW, Brown IH, Easterday BC, Van Reeth K. Swine influenza. In: Straw BE, Zimmerman JJ, D'Allaire S, Taylor DJ, editors. Diseases of swine. $9^{\text {th }}$ ed. Ames: Blackwell Publishing; 2006. p. 469-82.

Otte J, Hinrichs J, Rushton J, Roland-Holst D. Zilberman, D. Impacts of avian influenza virus on animal production in developing countries $C A B$ Reviews: Perspectives in Agriculture, Veterinary Science, Nutrition and Natural Resources 2008; 3(80) [cited 2012 April 21]. Available from: http://www.fao.org/docs/eims/upload//251044/aj201e00.pdf.

Otte J, Pfeiffer D, Soares-Magalhaes R, Burgos S, Roland-Holst D. Flock size and HPAl risk in Cambodia, Thailand, and Viet Nam. HPAI Research Brief 2007; 5: 4 [cited 2012 April 21]. Available from: http://www.hpai. research.net/docs/Research_briefs/FAO_2008_\%20HPAI_rbr05.-pdf.

Palese $\mathrm{P}$, Shaw ML. Orthomyxoviridae: the viruses and their replication. In: Knipe DM, Howley PM, editors. Fields virology. $5^{\text {th }}$ ed. Philadelphia: Lippincott Williams \& Wilkins; 2007

Pandemic H1N1 2009. Report of regional consultation on pandemic H1N1 2009 and strengthening country capacity for pandemic preparedness. Bangkok, Thailand; 2009.

Pantin-Jackwood MJ, Suarez DL, Spackman E, Swayne DE. Age at infection affects the pathogenicity of Asian highly pathogenic avian influenza H5N1 viruses in ducks. Virus Research 2007;130(1-2):151-161.
Park MS, Steel J, Sastre AG, Swayne D, Palese P. Engineered viral vaccine constructs with dual specificity: Avian influenza and Newcastle disease. PNAS 2006;103(21):8203-8208.

Pavlova SP, Veits J, Keil GM, Mettenleiter TC, Fuchs W. Protection of chickens against H5N1 highly pathogenic avian influenza virus infection by live vaccination with infectious laryngotracheitis virus recombinants expressing H5 hemagglutinin and N1 neuraminidase. Vaccine 2009; 27(5):773-785.

Perkins LE, Swayne DE. Pathobiology of A/chicken/Hong Kong/220/97 avian influenza virus in seven gallinaceous species. Veterinary Pathology 2001: 38: 149-164

Permin A, Detmer A. Improvement of management and biosecurity practices in smallholder poultry producers 2007. FAO: Husbandry Management Practices and Biosecurity [cited 2009 April 21]. Available from: http:// www.fao.org/docs/eims/upload/228410/biosecurity_en.pdf

Pisareva M, Bechtereva T, Plyusnin A, Dobretsova A, Kisselev O. PCRamplification of influenza $A$ virus specific sequences. Archives of Virology 1992; 125: 313-318

Pittman M. Annual Meeting, European Community, Report from the Commission $15^{\text {th }}$ Joint Annual Meetings of the National Laboratories for Newcastle Disease and Avian Influenza in Member States, Directorate General Health \& Consumers, Unit D1; 2009 Jun 3-4; Puławy. Poland.

Qi X, Li X, Rider P, Weixing F, Hongwei Gu, Longtao Xu, et al. Molecular characterization of highly pathogenic H5N1 avian influenza A viruses isolated from raccoon dogs in China. PLOS ONE 2009; 4(3): e4682 [cited 2010 May 10]. Available from: http://www.plosone.org/article/ info:doi\%2F10.1371\%2Fjournal.pone.0004682.

Quinlivan M, Zamarin D, Garcia-Sastre A, et al. Attenuation of equine influenza viruses through truncations of the NS1 protein. Journal of Virology 2005; 79(13):8431-8439.

Ramadan PA, Araujo FB, Ferreira MA. 12-month follow-up of an influenza vaccination campaign based on voluntary adherence: report on upperrespiratory symptoms among volunteers and non-volunteers. São Paulo Medical Journal 2001; 119: 142-145.

Rao P, Yuan W, Krug RM. Crucial role of CA cleavage sites in the capsnatching mechanism for initiating viral mRNA synthesis. EMBO Journal 2003; 22(5):1188-1198

Rapport sur I'influenza aviaire hautement pathogène à virus H5N1 d"origine asiatique. Ploufragan: Agence Française de Sécurité Sanitaire des Aliments; 2008.

Riner A, Chan-Tack KM, Murray JS. Intravenous Ribavirin - Review of the FDA's Emergency Investigational New Drug Database (1997-2008) and Literature Review. Postgraduate Medicine 2009; 121: 139-146.

Riquelme AM, Alvarez-Lobos C, Pavez P, Hasbun J, Dabanch C, Jimenez CJ, Calvo M. Gastrointestinal manifestations among Chilean patients infected with novel influenza A (H1N1) 2009 virus. Gut 2009; 58:1567-1568

Riviere-Cinnamond A. Compensation and related financial support policy strategy for avian influenza.emergency recovery and rehabilitation of the poultry sector in Vietnam. Rome: FAO; 2005. 39 p.

Roeder P, Masiga W, Bastiaensen P. Joint FAO/OIE/AU IBAR mission to Nigeria on highly pathogenic avian influenza. Rome: FAO/OIE AU-IBAR 2006. 30 p.

Roland-Holst D, Epprecht M, Otte J. External shocks, producer risk, and adjustment in smallholder livestock production: the case of HPAI in Vietnam. Rome: FAO-PPLPI Research Report; 2007. 20 p [cited 2011 Dec 23]. Available from: http://www.fao.org/ag/againfo/programmes/ en/pplpi/docarc/rep-hpai_adjustment-drh.pdf

Römer-Oberdörfer A, Veits J, Helferich D, Mettenleiter TC. Level of protection of chickens against highly pathogenic $\mathrm{H} 5$ avian influenza virus with Newcastle disease virus based live attenuated vector vaccine depends on homology of $\mathrm{H} 5$ sequence between vaccine and challenge virus. Vaccine 2008; 26(19):2307-2313

Roos R. WHO confirms H5N1 case in Pakistan cluster, CIDRAP, Center for Infectious Disease Research \& Policy; 2009 [cited 2011 Dec 23]. Available from: http://www.cidrap.umn.edu/cidrap/content/influenza/ avianflu/news/dec2707pakistan.html.

Rutala WA, Weber DJ. The healthcare infection control practices advisory committee (HICPAC). Clifton: Guideline for Disinfection and Sterilization in Healthcare Facilities; 2008. 
Sabartha N, Keith Howard M, Savidis-Dacho H, van Maurik A, P. Barrett $\mathrm{N}$, Kistner O.Comparison of single, homologous prime-boost and heterologous prime-boost immunization strategies against H5N1 influenza virus in a mouse challenge model. Vaccine 2010; 28(3): 650656.

Sasaki T, Kokumai N, Ohgitani T, Sakamoto R, Takikawa N, Lin Z, et al. Long lasting immunity in chickens induced by a single shot of influenza vaccine prepared from inactivated non-pathogenic $\mathrm{H} 5 \mathrm{~N} 1$ virus particles against challenge with a highly pathogenic avian influenza virus. Vaccine 2009; 27(38): 5174-5177

Schweiger B, Zadow I, Hecker R, Timm H, Pauli G. Application of a fluorogenic PCR assay for typing and subtyping of influenza viruses in respiratory samples, Journal of Clinical Microbiology 2000; 8 (4): 1552 1558.

Secretaria de Estado da Saúde. Situação epidemiológica da influenza pandêmica (H1N1) 2009, Influenza AviáriaH5N1 e vigilância sentinela da influenza, estado de São PauloBrasil. São Paulo (Brasil); 2011. Informe Técnico [cited 2012 March 23]. Available from: http://www. cve.saude.sp.gov.br/htm/-resp/pdf/IF11_INFLU300811.pdf.

Seo SH, Webster R. Cross-reactive, cell-mediated immunity and protection of chickens from lethal H5N1 influenza virus infection in Hong Kong poultry markets. Journal of Virology 2001; 75(6):2516-2525.

Shaman J, Kohn, M. Absolute humidity modulates influenza survival, transmission, and seasonality. PNAS 2009; 106(9):3243-3248.

Shaw M, Cooper L, Xu X, Thompson W, Krauss S, Guan Y, et al. Molecular changes associated with the transmission of avian influenza a H5N1 and H9N2 viruses to humans. Journal of Medical Virology 2002; 66(1):107-114

Shi H, Liu XF, Zhang X, Chen S, Sun L, Lu J. Generation of an attenuated H5N1 avian influenza virus vaccine with all eight genes from avian viruses. Vaccine 2007; 25(42):7379-7384.

Shinde V, Bridges CB, Uyeki TM, Shu B, Balish A, Xu X, et al. Triplereassortant swine influenza $A(H 1)$ in humans in the United States, 2005-2009. New England Journal of Medicine 2009; 360:2616-2625.

Shortridge KF, Zhou NN, Guan Y, Gao P, Ito T, Kawaoka Y, et al. Characterization of avian $\mathrm{H} 5 \mathrm{~N} 1$ influenza viruses from poultry in Hong Kong. Virology 1998; 252:331-342

Sims L. Long-term costs of HPAl control in Indonesia, Thailand, Viet Nam, Cambodia, Lao PDR, Hong Kong SAR and PR China. Rome: FAO; 2006.

Skeika N, Jabrb FI. Influenza viruses and the evolution of avian influenza virus H5N1 International Journal of Infectious Diseases 2008; 12(3): 233-238

Song $\mathrm{H}$, Nieto GR, Perez DR. A new generation of modified live-attenuated avian influenza viruses using a two-strategy combination as potential vaccine candidates. Journal of Virology 2007; 81(17):9238-9248.

Sorrell EM, Wan H, Araya Y, Song H, Perez DR. Minimal molecular constraints for respiratory droplet transmission of an avian-human H9N2 influenza A virus. Proceedings of the National Academy of Science USA 2009; 106(18):7565-7570.

Spackman E, Senne DA, Myers TJ, Bulaga LL, Garber LP, Perdue ML, Lohman K, Daum LT, Suarez DL. Development of a real-time reverse transcriptase PCR assay for type A influenza virus and the avian $\mathrm{H} 5$ and H7 hemagglutinin subtypes. Journal of Clinical Microbiology 2002; 40: 3256-3260, 2002

Special Report. Disaster risk. Beware the birds. China Economic Review 2007: 38-41

Stallknecht DE, Shane SM, Kearney MT, Zwank PJ.Persistence of avian influenza viruses in water. Avian Diseases 1990; 34(2):406-411.

Starick E, Römer-Oberdörfer A, Werner O. Type- and subtype-specific RTPCR assays for avian influenza A viruses (AIV). Journal of Veterinary Medicine 2000 b; 47: 295-301.

Steel J, Lowen AC, Pena L, Angel M, Solórzano A, Albrecht R, et al. Live attenuated influenza viruses containing NS1 truncations as vaccine candidates against H5N1 highly pathogenic avian influenza. Journal of Virology 2009; 83(4):1742-1753.

Steensels MS, Van Borm S, Van Den Berg S. Avian influenza: mini-review, European control measures and current situation in Asia. Avian Virology and Immunology, Veterinary and Agrochemical Institute (VAR) 2005: 104-120.

Suarez DL. Evolution of avian influenza viruses. Veterinary Microbiology $2000 \cdot 74(1-2): 15-27$
Subbarao K, Chen H, Swayne D, Mingay L, Fodor E, Brownlee G, et al. Evaluation of a genetically modified reassortant $\mathrm{H} 5 \mathrm{~N} 1$ influenza $A$ virus vaccine candidate generated by plasmid-based reverse genetics. Virology 2003; 305(1):192-200.

Subbarao K, Klimov A, Katz J, Regnery H, Lim W, Hall H, etal. Characterization of an avian influenza $A$ (H5N1) virus isolated from a child with a fatal respiratory illness. Science 1998; 279 (5349): 393-396.

Suguitan Jr AL, Marino MP, Desai PD, Chen L-M, Matsuoka Y, Hong Jin $\mathrm{D}$, et al. The influence of the multi-basic cleavage site of the $\mathrm{H} 5$ hemagglutinin on the attenuation, immunogenicity and efficacy of a live attenuated influenza A H5N1 cold-adapted vaccine virus. Virology 2009; 395 (2):280-288.

Suptawiwat O, Kongchanagul A, Chan-Ita W, Thitithanyanont A, Wiriyarat W, Chaichuen $\mathrm{K}$, et al. A simple screening assay for receptor switching of avian influenza viruses. Journal of Clinical Virology 2008; 42(2):186189

Swayne DE, Beck JR, Kinney N. Failure of a recombinant fowlpox vaccine containing an avian influenza hemagglutinin gene to provide consistent protection against influenza in chickens preimmunized with a fowl pox vaccine. Avian Diseases 2000a; 44:132-137.

Swayne DE, Garcia M, Beck JR, Kinney N, Suarez DL. Protection against diverse highly pathogenic H5 avian influenza viruses in chickens immunized with a recombinant fowlpox vaccine containing an $\mathrm{H} 5$ avian influenza hemagglutinin gene insert. Vaccine 2000b; 18: 10881095.

Swayne DE, Halvorson DA. Influenza. In: Saif et al, editor. Diseases of poultry. Ames: Blackwell Publishing; 2008. p. 153-184.

Swayne DE, Pantin-Jackwood M. Pathogenicity of avian influenza viruses in poultry. Developmental Biology (Basel) 2006; 124:61-67.

Swayne DE. Understanding the complex pathobiology of high pathogenicity avian influenza viruses in birds. Avian Diseases 2007; 51 (1 Suppl): 242-

Taha F. How highly pathogenic avian influenza (H5N1) has affected world poultry-meat trade. A Report from the Economic Research Service. United States Department of Agriculture; 2007 [cited 2012 Mar 28]. Available from: www.unitedpoultrygrowers.com/pdf docs/Outlook Report_Oct2007.pdf.

Thiry E, Addie D, Belák S, Boucraut-Baralon C, Egberink H, Frymus T, et al. H5N1 avian influenza in cats - ABCD guidelines on prevention and management. Journal of Feline Medicine \& Surgery 2009; 11(7):615618.

Ungchusak K, Auewarakul P, Dowell SF, Kitphati R, Auwanit W, et al. Probable person-to-person transmission of avian influenza A (H5N1). The New England Journal of Medicine 2005; 352(4):333-340.

USC - University of South Carolina. Environmental health \& safety.pandemic influenza cleaning \& disinfection [cited 2011 April 10]. Available from: http://ehs.sc.edu/hazwaste/environmental.htm.

USGS. An Early detection system for highly pathogenic H5N1 avian influenza in wild migratory birds U.S. interagency strategic plan [cited 2006 Mar 3]. Available from: http://alaska.usgs.gov/science/-biology/ avian influenza/pdfs/Final Wild Bird Stategic Plan_3-17a.pdf.

Veits J, Wiesner D, Fuchs W, Hoffmann B, Granzow $\bar{H}$, Starick E, et al. Newcastle disease virus expressing $\mathrm{H} 5$ hemagglutinin gene protects chickens against Newcastle disease and avian influenza. Proceedings of the National Academy of Sciences USA 2006; 103(21):8197-8202, 2006.

Villegas P. Viral diseases of the respiratory system. Poultry Science 1998; 77: 1143-1145

Webster RG, Webby RJ, Hoffmann E, Rodenberg J, Kumar M, Chu HJ, et al. The immunogenicity and efficacy against H5N1 challenge of reverse genetics-derived H5N3 influenza vaccine in ducks and chickens. Virology 2006; 351(2):303-311.

Wei-Hua, WH. The present status of the poultry industry in Guangdong Province. Poultry Husbandry and Disease Control 1998; 10: 1- 8

WHO. Regional Office for South-East Asia. Why are we concerned now? 2009a.

WHO. Regional Office for South-East Asia. Influenza pandemic of last century: some lesson; 2009b.

WHO. World Health Organization. Avian influenza: responding to the pandemic threat [cited 2010 Fev 10]. Available from: http://www.who. int/csr/disease/avian_influenza/guidelinestopics/en/index.html. 
WHO. World Health Organization. Avian influenza: responding to the pandemic threat [cited 2010 Dec 10]. Available from: http://www. searo.who.int.

WHO. World Health Organization. Cumulative number of confirmed human cases of avian influenza A(H5N1) reported to WHO [cited 2012 Mar 12]. Available from: http://www.who.int/influenza/human_animal_ interface/EN_GIP_20120312uCumulativeNumberH5N1cases.pdf.

WHO. World Health Organization. Influenza at the human-animal interface (HAl) [cited 2010 fev 27]. Available from: http://www.who.int/csr/ disease/en.

Wright PF, Neumann G, Kawaoka Y. Orthomyxoviruses. In: Knipe DM, Howley PM, editors. Fields virology. $5^{\text {th }}$ ed. Philadelphia: Lippincott Williams \& Wilkins; 2007. chapter 48.

Writing Committee of the Second World Health Organization Consultation on Clinical Aspects of human infection with avian influenza $A$ (H5N1) Virus. In: Abdel-Ghafar AN, Chotpitayasunondh T, ZGao Z, Hayden FG, Nguyen $\mathrm{DH}$, de Jong MD, et al. Update on avian Influenza A (H5N1) virus Infection in Humans. The New England Journal of Medicine 2008; 358(3):261-273 
